\title{
THE JUDICIARY AND DEMOCRACY IN GHANA'S FOURTH REPUBLIC
}

\author{
Isaac Owusu-Mensah and Joanna Rice \\ Isaac Owusu-Mensah is a senior lecturer in the Department of Political Science, \\ University of Ghana \\ Joanna Rice is a PhD candidate in the \\ Department of Political Science, University of Toronto
}

\begin{abstract}
Since the advent of multi-party elections in 1992, Ghana has successfully held six free and fair presidential and parliamentary elections, including the peaceful alternation of power on three occasions. Despite this impressive record, transparent and peaceful elections are never a guaranteed outcome in Ghana. General elections in the country are highly competitive and tightly contested by the two main political parties, the New Patriotic Party (NPP) and the National Democratic Congress (NDC) and their support bases. The 2016 general elections season was a fierce fight marked by apparent attempts at fraud and corruption on the part of the Electoral Commission. Although there was a tense lead-up to the vote, the elections proceeded without incident, largely due to the actions of the Supreme Court. These Supreme Court rulings on electoral transparency and fairness during the 2016 elections continue a long history of judicial intervention in electoral disputes. Nearly three decades of judicial activism has effectively constrained the major political parties in their ongoing attempts to use fraud and corruption for gains at the polls. This study thus supports the early work of Ruti Teitel on judicial policymaking in transitional states by demonstrating how an activist Supreme Court has effectively preserved and advanced democratisation in the face of weak political institutions.
\end{abstract}

Keywords: Ghana, democracy, judiciary, Electoral Commission, Supreme Court, elections 


\section{INTRODUCTION}

Ghana enjoys a reputation as a model of successful democratisation. Since the advent of multi-party elections in 1992, the country has successfully held six free and fair national elections, three of which resulted in a peaceful transfer of power. This outcome is even more impressive considering the number of neighbouring countries that are still recovering from recent electoral violence. Despite this commendable record, democratic consolidation and transparent elections are not a guaranteed outcome in Ghana (MacLean 2014, p. 93). Ghana's two dominant political parties compete in tightly contested national elections characterised by viciously fought campaigns. In recent elections both major parties demonstrated their willingness to use fraud and corruption in the hope of securing a win. The 2016 national election season was a fierce fight that took place in a tense political climate, and yet the election proceeded without incident and ended with a peaceful transfer of power. While there are multiple reasons for Ghana's demonstrated ability to overcome the ever-present threat of electoral crisis, this paper contends that the role of the Supreme Court as a mediator of potential fraud and corruption is of paramount consideration in Ghana's much vaunted electoral record.

A mandamus is a judicial order that compels a person or institution to perform their functions in accordance with the law. Over the past few decades Ghana's Supreme Court has produced such rulings, compelling the country's electoral institutions to act in free, fair and transparent ways. These rulings have built strong public trust in the judiciary as a mediator of electoral disputes, creating a constituency that prefers to take its grievances to court rather than into the streets. Thus, despite a demonstrated willingness to use nefarious and even corrupt tactics to win votes, the major parties have little choice but to accept the judiciary as the final arbitrator on electoral processes and results. There is a rich literature in legal studies debating the merits of judicial policy-making, particularly in moments of major societal upheaval. This study supports the early work of Ruti Teitel by demonstrating how an activist Supreme Court may be a means of preserving and advancing democratisation when faced with weak or transitional political institutions.

\section{POLICY-MAKING BY THE JUDICIARY}

Tate and Vallinder describe the 'judicialisation' of politics as one of the most significant trends of governance in the late $20^{\text {th }}$ and early $21^{\text {st }}$ century (Tate \& Vallinder 1992, p. 5). For these authors, to 'judicialise' politics refers to the increasing infiltration of judicial methods and actors into non-judicial governance sectors within the United States. The authors evince both enthusiasm and concern in their observation that judicial thinking and approaches to problem-solving are 
playing an ever more prominent role in governance: enthusiasm for a strengthened rule of law and concern for the implications this might have on the principle of the separation of powers.

The intellectual history of literature on judicialisation grows from a longstanding debate in legal studies between scholars of the judicial activism school and their interlocutors advocating for judicial restraints on the policy-making functions of national courts. Judicial activists advocate that judges ought to have an important policy-making role. These scholars see judges as guarantors that government actions should not only be consistent with the law, but should also be compelled to be just when legislation proves unethical. A judicial activist would, for instance, insist that the court should have the power to set a new precedent in defence of the most moral outcome possible, even if such a ruling goes against existing legislation or governing practices. In contrast, an advocate of judicial restraint would argue that the role of legislation and administration belongs exclusively in the hands of elected officials, and that the court's role is limited to interpreting those laws. Policy-making, in this view, is the sole prerogative of non-judicial institutions.

Judicial activism is an intellectual successor to legal realism. The central thesis of legal realism argues that judges base their adjudication on how the case moves them politically and morally. Essentially, these scholars argue that rather than applying existing legal sources or legal reasoning to judicial decisions, judges decide on a moral verdict and only subsequently seek legal justifications for that ruling (Bugaric 2001, p. 428). Legal realism became a prominent school of judicial thought in the 1920s and 1930s with authors such as Karl Llewellyn, Thurman Arnold, Max Radin, and Jerome Frank. The implication of the legal realism argument is that political ideology plays a much greater role in judicial outcomes than a strict reading of legal doctrine would suggest. In more contemporary literature, the legal realism school is updated by the works of Segal and Spaeth (2002) who refer to the approach as an 'attitudinal model' of judicial decisionmaking. The authors argue that justices should be free to decide cases based on their policy preferences due to the privileges bestowed on judges, which are based on their standing as highly regarded legal experts who have achieved lifetime tenure (Segal \& Spaeth 2002).

The legal process school is critical of legal realism, and is associated with scholars such as Lon Fuller, Henry Hart, Hans Kelsen, Tom Clark, Herbert Wechsler, John Hart Ely and Alexander Bickel. For these authors, there are both principled and practical arguments against allowing the power of the judiciary to expand into a policy-making body (Dun 2008, p. 3). In principle, judges lack legitimacy as national policy-makers; first, because their involvement in policy-making violates the separation of powers; and second, because they lack 
legitimacy as policy-makers because they are unelected representatives often coming from an economic and political elite (ibid. p. 5; Tate \& Vallinder 1992, p. 6).

In more practical terms, legal process writers further criticise the courts for overstepping their mandate because judges ultimately have no role in the implementation of policies they impose on an administration. For successful implementation, public policy requires coordination, negotiation and oftentimes horse-trading between a multitude of government actors (Fuller 1978, p. 357). Furthermore, policy decisions do not happen in a vacuum and require the allocation of budgetary and other resources, usually at the expense of other priorities. Courts are not in the position to perceive, let alone coordinate, the many competing interests and agendas that will need to be reconciled to effectively implement the policies they devise. Critics of legal activism refer to this practical challenge of policy implementation as a polycentric problem, noting that policymaking is a matter of managing competing interests, while legal decision-making is generally a binary analysis of the specific case appearing before the court (Dun 2008, p. 6).

Underlining the legal realist versus legal process debate is the central question of what political role courts can legitimately play in the governance of a democracy. The politicisation of courts was observed by Robert Dahl in his much cited 1957 article 'Decision-making in a democracy: the Supreme Court as national policy-maker'. While there is no controversy about high courts making decisions with political implication in their daily work, for Dahl the politicisation of a high court specifically refers to the extent that judges reach beyond precedent and constitutional law to establish a new legal alternative based on what is perceived as the best possible policy outcome (Dahl 1957, p. 565). The court's role in political decision-making is especially significant when such a decision clashes with a large segment of popular opinion. Dahl illustrates the risks but also the appeal of a politically active supreme court. He cites, amongst many examples, the American experience in which the Supreme Court intervened in cases of race segregation (ibid., p. 565). Indeed, throughout the 1960s and 1970s, the United State Supreme Court demonstrated the power and appeal of judicial activism by applying its influence to overcome institutionalised racial and gendered oppression in law and public policy (Rabkin 1983, p. 66). Thus, in democracies, high courts can play a unique role in protecting minorities against the oppression of an exploitative or intolerant politically powerful majority (Dahl 1957, p. 567).

As Marshal, Curry and Pacelle have illustrated, the legitimacy of court decisions depends upon the public perception that these are non-political institutions (2014, p. 38). Blurring the line between legal doctrine and policymaking risks inviting critique and potential loss of confidence from the public as well as colleagues in the legislature (Dahl 1957, p. 565). Essentially, the legal 
process school presents a paradox first described by Lori Hausegger and Lawrence Baum (1999, p. 170): maintaining some role in national policy-making requires carefully preserving the court's legitimacy by refraining from too active a role in policy-making. That said, empirical research by Gibson, Caldeira and Baird suggests that the risk of eroding the legitimacy of top courts is much less than suggested by the legal process theorists. In a study looking at public opinion towards high courts in eighteen countries, the authors discovered that supreme and constitutional courts are held in universally high esteem, with the public 'crediting the courts for pleasing decisions but not penalizing it for displeasing one' (Gibson, Calderia \& Baird 1998, p. 343).

Beyond issues of legitimacy, other critics warn that a highly activist supreme court exists in tension with democratic principle (Tushnet 1999, p.8). Legal process advocates see a limited role of the judiciary as not only necessary to preserve the legitimacy of the courts, but also as a practical necessity for democratic rule. Kelsen, an advocate of the legal process school of thought, presents the constitutional court as a 'negative legislator' with the primary purpose of monitoring the legal acts of parliament. The political role of the court is, essentially, limited to ensuring the alignment of government policy with statute law and constitutions (1942). This is because a court must respect the role and influence of the legislature should it wish, in turn, to continue seeing its own rulings respected and implemented by government officials (Clark 2009, p. 973; Gerhardt 2008). Legal process advocates therefore insist on the importance of maintaining a strong degree of separation between legislation and judicial practice both to preserve the legitimacy of the courts and to ensure the quality of democratic institutions.

Tushnet frames debate on role of the judiciary in policy-making around the risk of creating 'judicial supremacy'. He is describing a situation where courts amass too much authority compared to the legislatures (1999, p. 7). Judicial supremacy is a matter of how much policy-making power a court has over national legislation if, for example, it becomes

... emphatically the province and duty of the judicial department - and no one else - to say what the law is. [Such that] once [they] say what the law is... no one obliged to support the Constitution can fairly assert that the Constitution means something different.

(Tushnet 1999, p. 10)

Tushnet's main concern is with striking a balance between, at one extreme, the notion that courts can only advocate on policy questions on a case-by-case basis; and the other extreme position that the court's interpretation of any given case is akin to law henceforth in all related cases. 


\section{TRANSITIONAL DEMOCRACIES AND JUDICIAL POLICY-MAKING}

In recent years, the concept of judicialisation in politics has been taken up by scholars who observe the growing role of constitutional or supreme courts in governance as a global phenomenon. This thinking has produced a literature on the role of courts in transitioning democracies that parallels the legal activism and legal processes debate addressed above. Ruti Teital is credited with founding a new field of scholarship looking at the role of the judiciary in transitional states (1996). Favouring an activist approach to the role of the courts in democratic societies, Teitel understands political transitions as moments of ideological shift in the core meaning of law and justice in a society (ibid., p. 2014). She explains that in periods of political change, the law partially abandons its role as the source of order and stability in society to take on a guiding function in the normative transformation of moral and legal codes (ibid., p. 2029). As compelling as Teital's thesis may be, her position faces considerable pushback.

Others argue that in times of political transition it is especially important for the judiciary to defer power to the legislature, thus allowing elected policymakers to create new laws and a constitutional order less encumbered by the threat of judicial review (Bugaric 2001, p. 273).

Teitel's critics insist that courts do not have the legitimacy, the institutional power, or the capacity to develop and implement policy intended to push forward major social change. This position reflects the fact that, in legal theory, there is an inherent tension between the threat of judicial review and the success of democratisation. On one hand, the respect and authority often enjoyed by a high court can be leveraged to help advance and consolidate democratic values. On the other hand, overstepping the separation of powers to augment the role of courts in a democratisation process undermines a central tenet of democracy: the principle that only elected representatives should produce policy because they are ultimately accountable to constituents in a way that judges are not.

In a parallel critique, Stephen Holmes warns that placing too much confidence in the power of constitutional courts during major political transitions weakens the authority of legislative institutions that need bolstering at precisely these times of upheaval (1993). He explains that in moments of major political change, the overriding aim should be to strengthen the capacity of the legislature and executive, thus allowing these nascent institutions to earn the trust and respect of public opinion. When constitutional courts step in and do the work of legislating a transition, the power and legitimacy of the central government will suffer. On the other hand, courts may be necessary in times of transition to enforce rights and obligations that would be politically costly for legislators to defend. For instance, Landau refers to the key role of the constitutional courts 
in India, Colombia and South Africa, in defending socio-economic rights that are necessary for a successful transition yet are highly unpopular with some reactionary elements and hence potentially destabilising for the legislator (Landau 2014, p. 1052).

Further evidence from recent case studies suggests that, when allowed to act as a paramount authority during political transitions, the court can play an important role securing democratic practice and compensating for institutional weaknesses in the policy branches of government. The Constitutional Court in Colombia, for example, has actively sought to balance the institutional weakness of the legislature and executive in the wake of a protracted civil war and rampant state corruption. The Court openly critiques Congress in its statements and often overrules the political branches with judicial decisions (Landau 2014, p. 1514). Murison observes the high court in Uganda playing a key role in reducing electoral fraud there (2013, p. 496). Similar examples are seen in former Soviet states as new legal standards for the behaviour of government officials are being negotiated under the active authority of high courts (Bugaric 2001). In a counter example, allocating the court supreme authority on questions of political transition may erode democratic processes by concentrating power in the hands of a small number of unelected representatives. For example, the South African Supreme Court has long stood in open contestation with the post-apartheid government. This clash has reached such an extent that the Court often is criticised by the central state for attempting to run a judicial dictatorship (Ngang 2014, p. 657).

The central contention of this paper aligns with the thinking of the legal activist school. Looking at the work of Diana Kapiszewski, we emphasise that the risk the elected leaders in new or transitioning democracies often demonstrate is a 'propensity to disregard constitutional constraints' (2011, p. 497). New democracies face an immanent risk of slipping back into authoritarianism due to weak or corrupt political institutions. Kapiszewski posits that this risk can potentially be counterbalanced by courts acting as 'constitutional guardians' (ibid., p. 497). Similarly, for Taylor-Robinson \& Daniel (2012) the separation of powers should not necessarily be viewed as rigidly distinct spheres in a transitioning democracy. $\mathrm{He}$ argues that during moments when democratisation is challenged by the legislative branches of government, the overstep of judicial authority into policy-making is a legitimate democratic practice (2008, p. 15). Authors in this school of thought argue that democratic institutions benefit from strong constitutional courts which steer the country during times of political flux (Kapiszewski 2011, p. 497). When political institutions demonstrate their deficiency at enforcing democratic principles and the rights of citizens, it becomes legitimate, if not necessary, for courts to subject policy-makers to judicial review (Ngang 2014, p. 661; see also Ackerman 1997). 


\section{CASE STUDY}

Using the 2016 presidential elections in Ghana as a case study, this paper shows that the positive impact of judicial activism on governance in states with weak or transitioning political institutions is critical to the democratisation process. Despite its reputation as one of the most successful democracies on the African continent, Ghana consistently runs highly competitive national elections that are often marred by fierce confrontations between the main political parties. By serving as a bulwark against the threat of corruption and fraud in electoral institutions, the judiciary has emerged as a key protagonist in the Ghanaian electoral process. As discussed below, this role was especially significant in the tightly contested presidential elections that took place in December 2016, and the fact that Ghanaian elections are so competitive is one reason why Ghana is a democratic success story. This success can also be attributed to additional factors such as the development of a vibrant media, a resilient civil society, and the growth of democratic institutions.

\section{GHANA'S ELECTORAL HISTORY}

Ghana gained independence in 1957, the first sub-Saharan African country to do so, excluding settler-ruled South Africa. Since that time, the west African nation has followed an imperfect but consistent road towards consolidated democracy. Although Ghana's democratic project was delayed by military rule and authoritarian regimes in the years following independence, the country has since held peaceful and democratic elections for nearly three decades. Ghanaians have experienced six peaceful elections in a row since its transition to a multiparty democracy in 1992, including three non-violent transfers of power. This is despite ongoing challenges to the democratic process from highly antagonist major political parties who vie for power in a deeply divided and fiercely competitive electoral system. There are, of course, multiple reasons for the continuance of peace and stability despite a potentially volatile electoral system in Ghana. In this work, the role of the Supreme Court as a check on fraudulent behaviour by electoral institutions and political parties is a principal source of continued peace and stability in the face of constantly emerging threats to the democratic process.

Under the 1992 Constitution, all Ghanaians over the age of 18 with a national identity card enjoy universal suffrage by secret ballot. ${ }^{1}$ Presidential and parliamentary elections are held every four years, and presidents are limited to a two-term mandate. Should no clear winner emerge in the presidential elections

1 In addition to constitutional dictates defining electoral rules, the electoral process is also defined within the Representation of the People Law (PNDC Law 284) of 1992, Political Parties Act (Act 574) of 2000, and the Electoral Commission Act (Act 451) of 1993. 
with a fifty percent plus one victory in the first round of voting, there is a runoff election. Though officially a multi-party democracy, Ghana effectively has a two-party system with the New Democratic Congress (NDC) and New Patriotic Party (NPP) dominating the electoral scene. The NDC and NPP offer opposing ideological visions of the country that divides the population into two roughly equal political camps every four years. Albeit imperfect, party support in Ghana cuts across regional, ethnic and social cleavages (Whitfield 2009, p. 623). Through survey-based research, Ferree et al. (2009) determined that Ghanaian voters demonstrate a degree of party affiliation based on ethnicity; however, voting patterns do not strongly reflect support for ethnic groups. This is especially pertinent when contrasted with a strong tendency towards ethnic voting in other parts of west Africa.

The National Democratic Congress (NDC) is oriented towards social democracy. The NDC is associated with the Ewe ethnic group who represent approximately $13 \%$ of the population and are concentrated in the Volta Region along the Togo border (Ichino \& Nathan 2013, p. 348). The NDC also draws significant support from predominately Muslim regions in the north (Nathan 2016, p. 1906). It is associated with a statist development model for Ghana administered by a large and interventionist government. That said, during the early years of NDC rule the government of Ghana implemented an extensive IMF-mandated SAP program that radically reformed and reduced government size and spending (Ohemeng \& Anebo 2012, p. 162). The reforms arguably increased the efficiency of government and helped stabilise the national economy. However, a significant reduction in public services was keenly felt amongst the Ghanaian population, contributing to growing disillusionment with the longstanding NDC regime and the increased popularity of a new opposition party (Ohemeng \& Ayee 2016, p. 278).

The NPP emerged as a centre-right political party when Ghana returned to constitutional rule in 1992 after 12 years of military dictatorship. In their founding documents, the NPP committed to 'complete change from the NDC's shameful and depressing record that has led Ghana and Ghanaians into poverty and insecurity' (Ayee 2008, p. 193). The NPP is predominately affiliated with the Akan, Ghana's largest ethnic community encompassing $45 \%$ of the population (Ichino \& Nathan 2013, p. 348). The NPP is a centre-right party, closely associated with a market-led development model and commitment to the liberalisation of government, industry and the economy.

Both parties have regional strongholds of similar sizes. This means that electoral outcomes are ultimately determined by swing-regions where population groups loyal to neither party are concentrated. Fierce opposition between the two ideological visions for Ghana has resulted in highly competitive and frequently contested elections as the parties scramble to persuade swing-voters both with promises of their own generosity and by defaming their competitor. 


\section{THE ELECTORAL COMMISSION}

The first multi-party elections following the end of military rule in 1992 were easily won with a suspiciously large margin of victory by the former President Jerry John Rawlings. This dubious electoral outcome was fiercely contested by the NPP resulting in their boycott of the parliamentary elections four days later. The 1992 NPP boycott initiated an ongoing process of electoral reforms aimed at creating confidence in the country's new multiparty democratic system. Chief amongst these reforms was the creation of an Electoral Commission (EC).

In its early years the Electoral Commission enjoyed a high degree of credibility, due in large part to the personal appeal of its first Chairperson Kwadwo Afari-Gyan, who ran the EC from 1993 to 2015. As chairperson, AfariGyan announced the first successful defeat of the ruling NDC party in 2000, demonstrating to the electorate the effectiveness and trustworthiness of the EC (Cheeseman, Lynch \& Willis 2017, p. 99). The Commission further consolidated its credibility with the creation of the Inter-Party Advisory Committee (IPAC). This is a neutral political forum that allows representatives of all primary political parties to field concerns about the electoral process and discuss reforms in an ongoing way (ibid., p. 99). Thanks in large part to the influence of the EC, the 1996 electoral process was declared free and fair. This first successful election earned Ghana the praise and, perhaps more importantly, increased support of multinational donors (Piccolino 2016, p. 507). In 2000, power transferred once again: this time from the NDC back to the NPP, in a peaceful and transparent election (ibid., p. 508).

In the wake of the 2000 election new developments emerged to discredit the once widely respected Electoral Commission. Following the NDC win in 2012, the Electoral Commission confessed that the national voter registration list contained approximately 1.5 million 'ghost names' (Piccolino 2016, p. 508). The admission was especially damaging to the Commission's reputation given that the voter registration database had been completely overhauled only a few years earlier by the EC itself. The identified 'ghost voters' included names of voters who were dead, or minors - especially in the parties' respective strongholds. In a second major concern, the EC confessed that many foreign residents in Ghana were illegally registered on the voters' list.

The next major blow to EC credibility came during the 2008 election season. The final electoral results were extremely tight with fewer than 50,000 votes out of more than nine million determining the winners. Prior to the election, the EC was overwhelmed by nearly two million unanticipated new voter registrations. The subsequent disorder caused by the EC's lack of preparedness prompted a thorough investigation into the registration process, ultimately revealing that the EC registration activities that year were poorly administered and 'marred by violence and irregularities' (Piccolino 2016, p. 508). 
In 2012 once again, widespread allegations of 'over-voting' and registration 'irregularities' further damaged the credibility of the EC (Kwarteng 2014, p. 84). These 'irregularities' involved potentially tens of thousands of retained 'ghostnames' as well as the discovery of 'ghost' polling stations that were not on the official electoral list, yet had collected votes (Cheeseman, Lynch \& Willis 2017, p. 99). Despite acknowledging the existence of irregular voting, the Electoral Commission declared before the Supreme Court that the problem was not extensive enough to change the electoral results. Although the Supreme Court intervened to confirm the victory of NDC President Mahama in the 2012 elections, the court also mandated major reforms to the EC (Cheeseman, Lynch \& Willis 2017, p. 99).

In a context where elections are fiercely competitive and often determined by a small margin, the admission of error in voter registration on the part of the EC was a drastic blow to the Commission's credibility. More detrimental still to the EC public image, the NPP 2012 elections petition to the Supreme Court was broadcast publicly on national radio and television networks, capturing national attention with a theatrical confrontation between the parties, the Court and the EC. The highly publicised drama exposed endemic problems within the organisation, permanently marring the credibility of the Commission in the public eye (Kwarteng 2014, p. 86). ${ }^{2}$ In a December 2015 survey, a quarter of the respondents reported that 'they did not trust the EC at all' with only $24 \%$ of Ghanaians reporting that they trusted the EC 'a lot' (Cheeseman, Lynch \& Willis 2017, p. 99). Regardless of whether it is true that voter registration irregularities significantly affected electoral results in 2012, the situation has since resulted in a general sense amongst the Ghanaian public that both the voter list and the Commission itself are no longer credible.

The long-term impacts on Ghanaian democracy of electoral irregularities and a subsequent nationwide loss of confidence in the EC are potentially devastating. Given the tense context that has always surrounded national elections in Ghana, the failures of the Electoral Commission to remain partisan and credible meant that the institution designed to defend the sanctity of electoral transparency was now at the centre of national scandal. When the public does not trust that the institutions running elections are transparent and impartial, dissatisfied electoral losers can easily mobilise support for public disruption and, at times, violence, rather than accept an allegedly unwarranted loss. The loss of legitimacy experienced by the EC over the last decade could destroy Ghana's once-lauded democratic tradition. This was the political climate preceding the 2016 electoral

2 For instance, the national hearing revealed that the once-highly respected Commission Chairperson Kwadwo Afari Gyan had misrepresented his age on his own voter registration card, revealing that even the highest levels of the organisation were marred by a lack of credibility. 
season, with the NPP noisily predicting that the 2016 election would also be marred by what they perceived as a pro-NDC bias on the part of the Electoral Commission.

\section{ELECTIONS 2016}

The NDC government entered the 2016 electoral season initially confident of securing yet another victory. The government had invested heavily in industry and innovation during its most recent tenure in office, resulting in a major jump in the GDP from 4.1\% in 2015 to 5.4\% in 2016. Despite the impressive growth rate, most Ghanaians felt only the negative side of rapid economic growth. For most Ghanaians, the NDC regime's economic success story meant high inflation and growing commodity prices. Meanwhile, infrastructure continued to crumble and youth unemployment reached nearly 50\% (Cheeseman, Lynch \& Willis 2017, p. 94). In the months before the December 2016 election, signs began to appear in the NDC's own strongholds reading 'No lights, no votes'. Mounting evidence showed that many Ghanaians wanted a major government overhaul and were ready to throw out the incumbent NDC.

Simultaneously, fears circulated that the Electoral Commission would rig the election in favor of the NDC. The NPP fears that the Electoral Commission was biased in favor of the NDC were intensified when the Commission's chairperson was replaced in 2015 by Ms. Charlotte Osei (Cheeseman, Lynch \& Willis 2017, p. 93). As the former chairperson of the National Commission for Civic Education, Ms. Osei had a long history of close collaboration with the NDC government. Confirming the NPP worries, the 2016 election saw Ms. Osei 'on the wrong side of significant court litigation' leading up to the election (Akoto to Charlotte Osei, November 3, 2016). Amongst numerous troubling actions on the part of the EC, she defended significant errors in the voter registration list before the Supreme Court. Also, under Ms. Osei's leadership, the EC unsuccessfully attempted to adopt a non-transparent methodology for tallying electoral results that would keep candidates ignorant of the numbers until the EC had finished its overall count. Finally, the 2016 election saw the disqualification of all but four presidential candidates based on bureaucratic technicalities (Nyabor 2016).

\section{SUPREME COURT INTERVENTION}

In the lead-up to the 2016 Election, the Electoral Commission found itself before the Supreme Court with a series of accusations of potential corruption. The Supreme Court ruling in favour of the incumbent NDC following the 2012 election was accompanied by list of instructions to the Electoral Commission requiring 
substantial reforms to its operations, mostly regarding the voter registration process. This prompted the NPP to write the Electoral Commission a note filing its concerns about the damaged credibility of the EC, particularly considering the persistent presence of fraudulent voters on the national registration list. The petitioners argued that many names appearing on the Ghana voter registration list were also seen on voter lists in Cote d'Ivoire, Burkina Faso and Togo and therefore could not be eligible as voters in Ghana. The second issue raised was with regard to registration by National Health Insurance cards, which the state does not recognise as an official form of citizenship identification. When the EC ignored the letter, the NPP took their concerns over the voter list and other irregularities in the electoral process to the Supreme Court.

\section{VOTER REGISTRATION IRREGULARITIES}

Voter registration has always been a major challenge to the success of free and fair elections in Ghana. National identification cards were introduced in 1970; however, the process was interrupted by a military coup d'état before the service could be provided to the entire country. With significant gaps in national coverage of the required identity documents, many Ghanaians registered to vote with a self-approval process (Piccolino 2016, p. 506). For example, it was once common practice for two qualified voters to accompany the applicant to the registration office as witnesses and verbally confirm identity without the requirement of a national ID. Although biometric voting was introduced before the 2012 election, a significant number of ghost names continue to exist on the national register that the EC has been unable to identify and remove despite ongoing efforts to clean the list. Without a reliable registration process, both major parties accuse the other of encouraging their supporters to double-vote (ibid., p. 508).

Prior to the 2016 election, the Electoral Commission faced a petition that reached the Supreme Court in a case entitled Abu Ramadan II. Abu Ramadan II of the PNC party and Nimako from the NPP brought the Electoral Commission before the Court demanding that the names of ineligible voters be removed immediately from the voter list. The petitioners accused the EC of allowing voters to register with a National Health Insurance card as an official state identification. The insurance cards are available to all residents of Ghana regardless of whether the individual is an eligible voter, sparking concern that the cards were used by foreigners living in Ghana to illegally register and vote. This phenomenon is highly controversial due to the geographic concentration of NDC and NPP's respective strongholds. The NDC enjoys a significant support base amongst foreign migrants in Ghana, especially in the predominantly Muslim region of the North (Nathan 2016, p. 1906). To the extent that ethnicity does predict voter choice in Ghana, allowing NHIS card holders to register to vote disproportionally benefits the NDC. 
On May 5 2016, the Supreme Court released its verdict stating that the use of National Health Insurance Service (NHIS) cards for the purposes of voter registration was unconstitutional, and that all such registrations became invalid with immediate effect. The following unanimous court decision was read by Justice Gbadegbe:

... The 1st defendant (that is, the Electoral Commission) \{must\} take immediate steps, that is, forthwith, to take steps to remove from the current register of voters all persons who had used NHIS cards to register. This order having been made under Article 2(2) of the Constitution therefore takes precedence over any existing statutory provision... In order not to violate their fundamental electoral rights and in order not to disenfranchise such persons, the EElectoral Commission must give adequate notice to those affected by the order of the processes of deletion and re-registration, subject to eligibility. The removal of the names from the register $\{\ldots\}$ precedes the processes of re-registration ...

(Akoto \& Kwasi Prempeh 2016)

As is clear in the statement above, the court further ordered the Commission to present the 56772 voter names removed from the list with reasonable accommodation needed to re-register with an official form of identification as provided by the Constitutional Instrument 91. On July 13 2016, the Electoral Commission announced that it had deleted the NHIS registered voters. Also, in compliance with the Supreme Court ruling, the EC publicly released the list of deleted names and gave a ten-day window for re-registration.

Before complying, however, the EC defended its initial voter list by claiming that the EC benefitted from a constitutionally-protected independence from the oversight of all other government entities (ibid.). This stance, however, reflected a misinterpretation of the constitutional protections of Electoral Commission independence. Should an act or action of the Commission be deemed unconstitutional by the Supreme Court, the Court is vested with power under the Constitution (Article 2(2)) to compel the EC to take steps necessary to correct the violation (Allotey 2016). Akoto Ampaw, a prominent Ghanaian constitutional lawyer, confirms that a declaration by the Supreme Court of unconstitutional behaviour by another state entity takes precedence over any other statutory provision, including provisions that are themselves guaranteed by the constitution, such as the independence of the EC (Akoto \& Kwasi Prempeh 2016).

This ruling is significant for the long-term prospects of Ghanaian democracy. Aside from resolving inconsistencies in the voter registration process, Abu 
Ramadan II demonstrated that the Supreme Court has the authority to overrule the independence of the Electoral Commission in instances when the former acts in ways deemed unconstitutional by the Court itself. For Ampaw, the case touched on what he considers the most fundamental question in a constitutional democracy: the meaning of the supremacy of the constitution (ibid.). The case, he writes, offered an 'authoritative and clear resolution of this matter'. The Court ruled on its own behalf that it requires 'no existing or new legislation' to demand any other governance institution to rectify actions deemed unconstitutional (Allotey 2016).

\section{NON-TRANSPARENT METHODS FOR ANNOUNCING VOTE RESULTS}

A second case regarding the release of electoral results was heard by the Supreme Court on 27 October 2016, few weeks before the December elections. The plaintiffs complained to the Supreme Court about a recently adopted EC method for collecting and tallying polling station results. The new methodology appeared to reduce the transparency of the vote-counting process significantly, thus opening the way for possible fraud and abuse by political parties and the EC. The NPP was specifically concerned with vote-counting documents known as Presidential Election Result Collation Forms. These are the 275 forms of compiled results collected from about 29000 polling stations across the country. Akoto Ampaw, lead counsel on the case, argued that the new counting methods concealed electoral collation forms from the opposition during the counting process. This means that only the Electoral Commission itself would have access to the polling station results prior to compiling a national tally (Kwesi Nyame-Tsease Eshun vs. Electoral Commission, 2016).

Akoto and his fellow legal counsellors warned that the new counting methods left a dangerous gap in the transparency of the electoral process. Moreover, it was a gap that could easily be exploited by the Electoral Commission to skew results in favor of the incumbent NDC party. The matter was of particular concern because, following the 2012 elections petition verdict, the Electoral Reforms Committee had already recommended that the collation forms be made available to agents of candidates and then signed to confirm that all electoral procedures were duly and fairly performed. The EC, however, had ignored the recommendation and this roused suspicions amongst the political opposition that the EC was adopting a new non-transparent policy on precisely the issue it was previously instructed to reform (ibid.).

The Supreme Court ruled that the existing legislation regarding collation forms: 
... is unreasonable, unfair, non-transparent and does not promote or secure free and fair elections and is accordingly inconsistent with... the Constitution and the core constitutional values of transparency, accountability and the rule of law. (ibid.)

The Court ruling henceforth requires the EC to present agents of each candidate with polling station results as that information is compiled. Ensuring that the collation forms were made available to and endorsed by representatives of each candidate meant the political parties could verify official election results against their own count. This added layer of transparency reduced the fear of cheating by the EC, and subsequently helped elevate tension in the lead-up to the 2016 Ghanaian election (Daily Statesman 2016).

\section{EXCLUSION OF PRESIDENTIAL CANDIDATES}

A third Supreme Court ruling took place during the 2016 electoral season on the issue of presidential candidate disqualifications. The Electoral Commission disqualified 13 out of 17 presidential candidates, citing anomalies on their nomination forms (Delali 2016). ${ }^{3}$ According to the EC, some candidates did not properly sign their nomination forms, others provided insufficient registration fees, while still others had listed ineligible sponsors for their candidature. The High Court overruled the disqualifications, prompting the Electoral Commission to take the matter to the Supreme Court. Faced with court cases from all the major political parties, the EC hoped for reprise from the Supreme Court. ${ }^{4}$ Instead, the SC ruled that candidates could not be denied participation in national elections based on minor errors in their application forms and must be given due accommodation to allow their registration. The court gave its verdict on the legality of the disqualification of the Progressive People's Party (PPP) candidate Dr. Papa Kwesi Nduom, ruling that the Dr. Nduom must be given adequate opportunity to register in the presidential race. This decision automatically applied to the other disqualified candidates. In response to the Supreme Court decision, the legal counsel for Dr. Nduom announced, 'Some people (namely, the EC) tried to create the impression that the disqualified candidates were involved in fraudulent activities. I am very happy that the Supreme Court has told the EC to live by the law' (Aku Baneseh \& Ebo Hawkson 2016).

3 The four candidates originally accepted were Nana Addo Dankwa Akufo-Addo of the New Patriotic Party (NPP), John Dramani Mahama of National Democratic Congress (NDC), Ivor Kobina Greenstreet of the Convention People's Congress (CPP) and Jacob Osei Yeboah (JOY), an independent candidate. 


\section{AN ELECTORAL CRISIS AVERTED}

On December 72016 , Ghanaian voters and political parties peacefully navigated a 'high-stakes, highly competitive election that many had feared would strain their country's political stability to the breaking point' (Cheeseman, Lynch \& Willis 2017, p. 92). The election ended with the peaceful transfer of power from the NDC incumbent to the NPP opposition party. The election and subsequent handover of power proceeded without serious incident, and the elections themselves were widely recognised both at home and abroad as free, fair and transparent.

As discussed above, this was not the first time the Supreme Court had intervened to defend the democratic process in Ghana. In 2012, the Court demonstrated its role as a guarantor of peaceful conflict resolution by rejecting an appeal from NPP candidate Nana Akufo-Addo, asking the court to cancel $40 \%$ of the 11 million votes, alleging voter fraud (Kwarteng 2014, p. 83). Over a period of fifty sessions, the Court ultimately confirmed the incumbent NDC candidate John Mahama as president, striking down the NPP petition. In 2008, the Court also intervened to ensure a peaceful outcome to the highly competitive election fraught with charges of fraud and other irregularities. For Abdulai and Crawford, these successes are clear evidence that Ghana is a consolidated democracy in the sense that there are 'no significant political groups seriously attempting to overthrow the democratic regime' (2010, p. 32).

For Kwarteng, Ghana's Supreme Court is accredited with the role of judicial exorcism by serving as a barrier to political extremism in the electoral system (2014, p. 88). As a case in point, Justice William Atuguba, former head of the ninemember Supreme Court Panel, publicly lashed out at the primary political parties in 2008. Accusing them of seeking to destroy the political institutions in Ghana for their own profit, Justice Atuguba warned the parties that - if necessary - the Court would 'marshal its state-conferred power to contain the political class' (Kwarteng 2014, p. 89). As further evidence that the Supreme Court considers itself a barrier to the risk of electoral crisis in Ghana, the Court has published a manual explaining to political parties and civil society how to access the court and invoke its participation in dispute resolution (Abdulai \& Crawford 2010, p. 36).

The 1992 Constitution gives the Supreme Court of Ghana authority to rule on the constitutionality of all other state entities including independent commissions such as the EC. The 2016 election clearly demonstrated the ability and willingness of Ghana's highest court to compel state institutions to end any unconstitutional behaviour with the ruling known as mandamus orders. Using this judicial power, the Court has consistently cast itself between the political parties, acting as a bulwark against encroaching corruption and the threat of violence in Ghana's elections. This became especially clear in the 2016 election as the Court actively 
intervened to block suspicious activities on the part of the Electoral Commission in the lead-up to the national vote.

Abdulai and Crawford accredit the peaceful transfer of power through democratic processes in Ghana for over two decades to a commitment from the dominant political parties to rely on appropriate institutions to resolve disputes and grievances (2010, p. 35). Yet, over the last few decades both major political parties have also demonstrated their willingness to use corruption and other hostile tactics to win the national vote. Cooperation between the NDC and NPP is notoriously poor, with both parties often adopting defamatory campaigns against the other (Ayee 2008, p. 208). In the 2016 election, the NDC party exercised its power as an incumbent to undermine the independence of the Electoral Commission. It is therefore the contention of this paper that, rather than accrediting politicians with a commitment to democratic practice as Abdulai and Crawford appear to do, the more important element in the success story of Ghanaian democratisation is the activism of the Supreme Court.

The willingness of Ghana's main political parties to take their concerns with the electoral process before the Supreme Court is not evidence that these parties are committed to a free and fair democratic procedure. As seen in the cases cited above, both main parties are perfectly willing to undermine the democratic process in hopes of securing a win. Instead, the Court has proven itself strong enough and reliable enough in the public eye that the political parties have no choice but to respect judicial rulings. Robert Dahl has famously stated that when rulers face mounting opposition, they can either reform or repress. For Cheeseman et al., the willingness of Ghanaian incumbents to reform rather than repress is evident in the Ghanaian electoral success over the last decades, especially in the case of the peaceful transfer of power in 2016 (Cheeseman, Lynch \& Willis 2017, p. 100). This article seeks to qualify Dahl's statement by noting a potential third option in which the role of an activist Supreme Court has constrained potentially repressive politicians and the arrogance of state institutions so effectively that they have no choice but to reform.

Having achieved more than two decades of free and fair electoral proceedings, Ghana is considered a model of democratisation in its region. Yet, despite the outward image of consistent electoral successes, this reputation has faced serious threats over the last decade due to the tightly competitive nature of electoral results in Ghana and the hostile political environment created by both major parties around elections. With the addition of mounting controversies resulting from non-transparent EC behaviour, these threats to free and fair democratic procedure came to a head in the lead-up to the 2016 vote. And yet, despite these challenges, Ghanaians once again proved to its credit the global reputation of being a democratic model in Africa and worldwide. 


\section{CONCLUSION: AN ACTIVIST SUPREME COURT AS GUARANTOR OF DEMOCRATIC PRACTICE}

There are certainly multiple factors behind this achievement; however, the role of an activist Supreme Court in defending democratic procedure is clear in the Ghanaian case. The legal process school discussed in the opening sections of this paper warns that an overly active supreme court risks eroding the legitimacy of the judicial system in the public eye and in the eyes of the legislative authority. In Ghana we see the opposite. An activist Supreme Court has instead built enough confidence in the political parties through its interventions in electoral politics to ensure that election-related complaints are now reliably brought to court rather than being worked out in the streets. These findings support the position advanced by Ruti Teitel that weak democratic institutions require interference from a strong Supreme Court to act as an ethical guide and mediator for the rest of governance. As a case in point, during the 2016 national elections in Ghana suspicious behaviour on the part of the Electoral Commission was exposed and corrected by the Court before these issues could create a national crisis.

We should not underestimate the serious challenges to democracy that the fiercely opposed political parties present, especially in a highly competitive electoral environment. To appreciate the important role the Supreme Court has played in preserving peace in the face of potential electoral crisis, we need look only to recent events in Ghana's regional neighbourhood. During the last decade, corrupt or weak democratic institutions were at the centre of electoral crises that dissolved into civil war in Cote d'Ivoire, The Gambia, Gabon and Central African Republic. Also, prior to the democratic renewal in Ghana in 1992 that created Ghana's Fourth Republic, political polarisation did reach violent extremes, resulting in a coup d'état and ten years of military rule. Despite its location in a bad neighbourhood when it comes to electoral crises, contemporary Ghana has retained its reputation as a model for peaceful democratisation. This paper contends that this success should be attributed in large part to the activist role of the Supreme Court. As seen in the case study above, the Ghanaian high court has built enough credibility to effectively constrain an ever-present threat of undemocratic practice on the part of Ghana's main political parties. As Teitel predicted, the willingness of the Supreme Court to intervene when other democratic institutions fail has today ensured that in Ghana potential electoral crises are brought before the judges rather than ending in crisis. 


\section{--_-- REFERENCES}

Ackerman, B 1997, 'The 'rise of world constitutionalism', Virginia Law Review, vol. 83, pp. 771-797.

Abdulai, A-G \& Crawford, G 2010, 'Consolidating democracy in Ghana: progress and prospects?', Democratization, vol. 17, pp. 62-67.

Akoto, A 2016, 'Ampaw Akoto to Charlotte Osei: regarding election timetable and $7^{\text {th }}$ December 2016 General Elections', Electoral Commission Accra, Ghana, November 3.

Akoto, A \& Kwasi Prempeh, H 2016, 'Abu Ramadan III: clarification ruling and orders and the Electoral Commission', CitiFM Online, July 20, citifmonline. com/2016/07/20/abu-ramadan-iii-clarification-ruling-orders-the-ec/

Aku Baneseh, M \& Ebo Hawkson, E 2016, 'Lifeline for disqualified aspirants as Supreme Court orders EC to extend nomination period', Graphic Online, November 8, http://www.graphic.com.gh/news/general-news/lifeline-fordisqualified-aspirants-as-supreme-court-orders-ec-to-extend-nominationperiod.html

Allotey, GA 2016, 'Abu Ramadan to file case challenging NHIS registrants list today', CitiFM Online, July 4 , http://citifmonline.com/2016/07/04/abu-ramadan-tofile-case-challenging-nhis-registrants-list-today/

Ayee, J 2008, 'The evolution of the New Patriotic Party in Ghana', South African Journal of International Affairs, vol. 15, pp. 185-214.

Bugaric, B 2001, 'Courts as policy-makers: lessons from transition', Harvard International Law Journal, vol. 42, pp. 247-288.

Cheeseman, N, Lynch, G \& Willis, J 2017, 'Ghana: the ebbing power of incumbency', Journal of Democracy, vol. 28, pp. 92-104.

Daily Statesman, 2016, 'Latest Supreme Court writ exposes EC on collation sheet', GhanaWeb, October 24, https://www.ghanaweb.com/GhanaHomePage/ NewsArchive/Latest-Supreme-Court-writ-exposes-EC-on-collationsheet-480363

Dahl, R 1957, 'Decision-making in a democracy: the Supreme Court as a national policy-maker', Journal of Public Law, vol. 6, p. 279.

Delali, A-B 2016, 'PNC threatens Supreme Court lawsuit over nomination forms if...' CitiFm Online, November 8, http://citifmonline.com/2016/11/08/pncthreatens-supreme-court-lawsuit-over-nomination-forms-if/

Dun, J 2008, 'The perils of judicial policymaking: the practical case for separation of powers', Heritage Foundation, vol. 20, pp. 1-13.

Ferree, K, Gibson, C, Hoffman, B \& Long, J 2009, 'Explaining the African vote', Working Paper University of California San Diego.

Fuller, L 1978, 'The forms and limits of adjudication', Harvard Law Review, vol. 92, pp. 354-409. 
Gerhardt, M 2008, The power of precedent, Oxford University Press, New York. Gibson, JL, Caldeira, GA \& Baird, VA 1998, ‘On the legitimacy of national high courts', The American Political Science Review, vol. 92, pp. 343-358.

Holmes, S 1993, 'Back to the drawing board: an argument for constitutional postponement in Eastern Europe', East European Constitutional Review, vol. 2, pp. 21-25.

Kelsen, H 1942, 'Judicial review of legislation: a comparative study of the Austrian and the American Constitution', The Journal of Politics, vol. 4.

Ichino, N \& Nathan, N 2013, 'Crossing the line: local ethnic geography and voting in Ghana', American Political Science Review, vol. 107, pp. 344-361.

Kapiszewski, D 2011, 'Tactical balancing: high court decision making on politically crucial cases', Law and Society Review, vol. 45, pp. 471-506.

Kwarteng, C 2014, 'Swords into ploughshares: the judicial challenge of Ghana's 2012 presidential election results', The Round Table, vol. 103, pp. 83-93.

Landau, D 2014, 'Dynamic theory of judicial role', Boston College Law Review, vol. 55, pp. 1501-1562.

Hausegger, L \& Baum, L 1999, 'Inviting Congressional action: a study of Supreme Court motivations in statutory interpretation', American Journal of Political Science, vol. 43, pp. 162-185.

MacLean, L 2014, 'Citizen or client? an analysis of everyday politics in Ghana', African Studies Quarterly, vol.15, pp. 93-124.

Marshal, BW, Curry, BW \& Pacelle, RL 2014, 'Preserving institutional power: the Supreme Court and strategic decision making in the separation of powers', Politics and Policy, vol. 42, pp. 37-76.

Murison, J 2013, 'Judicial politics: election petitions and electoral fraud in Uganda', Journal of Eastern African Studies, vol. 7, pp. 492-508.

Nathan, N, 2016, 'Local ethnic geography, expectations of favoritism, and voting in urban Ghana', Comparative Political Science, vol. 49, pp. 1896-1929.

Ngang, CC 2014, 'Judicial enforcement of socio-economic rights in South Africa and the separation of powers objection: the obligation to take "'other measures",' African Human Rights Law Journal, vol. 14, pp. 655-680.

Nyabor, J, 2016, 'Charlotte Osei must be impeached: Martin Amidu', CitiFM Online, November 15, http://citifmonline.com/2016/11/15/charlotte-osei-must-beimpeached-martin-amidu/

Ohemeng, FLK \& Anebo, F 2012, 'The politics of administrative reforms in Ghana: perspectives from path dependency and punctuated equilibrium theories', International Journal of Public Administration, vol. 35, pp. 161-176.

Ohemeng, FLK \& Ayee, JRA 2016, “The “New Approach" to public sector reforms in Ghana: a case of politics as usual or a genuine attempt at reform?', Development Policy Review, vol. 34, pp. 277-300. 
Piccolino, G 2016, 'Infrastructural state capacity for democratization? voter registration and identification in Cote d'Ivoire and Ghana compares', Democratization, vol. 23, pp. 498-519.

Rabkin, J 1983, 'The judiciary in the administrative state', The Public Interest, vol. 1, pp. $62-84$.

Teitel, R 2009, 'Transitional jurisprudence: the role of law in political transformation', Yale Law Journal, v. 106, pp. 1996-2080.

Segal, J \& Spaeth, H 2002, The Supreme Court and the attitudinal model, Cambridge University Press, Cambridge.

Tate, N \& Vallinder, T 1995, The global expansion of judicial power, NYU Press, New York.

Taylor-Robinson, MM \& Ura, JD 2012, ‘Public opinion and conflict in the separation of powers: understanding the Honduran coup of 2009', Journal of Theoretical Politics, pp. 1-23.

Tushnet, M 1999, Taking the Constitution away from the courts, Princeton University Press, Princeton, NJ.

Whitfield, L 2009, 'Change for a better Ghana: party competition, institutionalization and alternation in Ghana's 2008 elections', African Affairs, vol. 108, pp. 621-641. 